\title{
STUDENT CONSULTANTS OF COLOR AND FACULTY MEMBERS WORKING TOGETHER TOWARD CULTURALLY SUSTAINING PEDAGOGY
}

\author{
Alison Cook-Sather, Praise Agu \\ Bryn Mawr College
}

Through positioning undergraduate students as pedagogical consultants to college faculty, Students as Learners and Teachers is a program that provides reconceptualized "counterspaces" for students and faculty members with whom they work. In our study of the experiences of consultants of color, we found that those students and their faculty partners used program counterspaces to explore links between their lived identities and pedagogical commitments and to share authority and responsibility in developing culturally sustaining pedagogy. In this chapter we report on participants' experiences in these collaborations and how they legitimate the knowledge of students of color in faculty learning.

Thanks to Jody Cohen, James Groccia, Toni King, Elliott Shore, Steve Volk, Alicia Walker, and three anonymous reviewers for insights developed within and responses to drafts of this chapter. 
Over twenty years ago, Allen (1992) asserted that "far-reaching, enduring change in higher education ... will only come about when universities come to feel more keenly their responsibility for changing the system of unequal societal relationships based on racen (p. 42). Working toward that end, scholars have argued for the development of "culturally sustaining pedagogy" (Paris, 2012) that recognizes and values diverse students (Colbert, 2010; Fasching-Varner \& Seriki, 2012; Gay, 2002; Pappamihiel \& Moreno, 2011) "while simultaneously offering access to dominant cultural competence" (Paris, 2012, p. 95). Such practices mitigate the need for students from underrepresented groups to seek or create "counterspaces" - academic and social spaces on and off their campuses "where deficit notions of people of color can be challenged and where a positive collegiate racial climate can be established and maintained" (Solórzano, Ceja, \& Yosso, 2000, p. 70).

The Students as Learners and Teachers (SaLT) program at Bryn Mawr College redefines counterspaces, framing them as institutionally valued forums that affirm students of color rather than alternative arenas necessary to counterbalance "the daily barrage of racial microaggressions that [students] endure both in and outside of their classes" (Solórzano et al., 2000, p. 70). The program creates opportunities for students of all identities to share their perspectives and partner with faculty in explorations of teaching and learning, but in this discussion, we focus on how it provides spaces wherein students of color are recognized as "holders and creators of knowledge" (Delgado-Bernal, 2002, p. 106) and that knowledge becomes a resource for faculty learning.

We begin with a description of the SaLT program and its redefined counterspaces. We then situate the program at the intersection of scholarship on student voice, faculty development that includes students as partners, and critical race theory. Finally, drawing on the words of student consultants and their faculty partners, we describe the ways in which student and faculty participants have used the counterspaces of the program to share authority and responsibility for developing culturally sustaining pedagogy. Their work models how new kinds of counterspaces can change who participates in shaping educational practice and who contributes to institutional change.

\section{The Students as Learners and Teachers Program as Counterspace}

The SaLT program is part of the Teaching and Learning Institute at Bryn Mawr College, supported by a grant from the Andrew W. Mellon 
Foundation and the provosts at Bryn Mawr and Haverford Colleges. SaLT invites undergraduate students to take up the paid position of pedagogical consultant to college faculty who choose to participate in the program. Faculty and student pairs work in semester-long partnerships to analyze, affirm, and revise the faculty member's pedagogical approaches in a course as she or he teaches it.

Each week the consultant observes her faculty partner's classroom, shares her observation notes, and meets with her partner to discuss what is working well and what might be revised. Student consultants apply for this paid position (they must submit an explanation of why they want to assume this role, procure letters of recommendation from a faculty or staff member and a student, and sign a confidentiality agreement). They attend an orientation, receive a set of guidelines for developing partnerships with faculty members, and participate in weekly meetings with the first author of this chapter, Alison, in her role as coordinator of the program, and other consultants. In these meetings, they discuss how best to partner with faculty in the work of recognizing the diverse experiences and perspectives students bring to their studies and developing classrooms that are both welcoming and productively challenging.

Between 2006 and 2012, 150 faculty members participated in over 225 partnerships. Of the 90 students who assumed the role of pedagogical consultant in those years (many of them for more than one semester), 49 were students of color or international students. As part of an ongoing action research project Alison has maintained for six years, she, who selfidentifies as a white woman, and Praise, the second author of this chapter and an experienced student consultant who self-identifies as African American, conducted a study during the spring 2012 semester through which we focused on the experiences of 16 students who self-identify as people of color and were able to complete a survey or participate in a focus group, or both. (This chapter does not address the experiences of international students.)

In contrast to the "spaces of marginality" (Huber, 2009, p. 710) in which many students of color must develop "cultural wealth" (Solórzano, Villalpando, \& Oseguera, 2005), the SaLT program creates counterspaces that are central to student empowerment and faculty learning. In these redefined counterspaces-the program itself and its weekly meetings of same- and cross-constituency participants-student consultants have, as one consultant explained, "a space to share [their] unique experience, a space to listen, and a space to engage," all of which, consultants find, "affirm who I am." Furthermore, because student consultants are "not responsible for the content [and] free of the grading," as one faculty 
member put it, they can, according to another faculty member, talk about their experiences as students of color "in a frank way that I appreciated." The culture and hierarchy of higher education do not generally encourage or support such exchanges; by making them the focus of faculty learning, the SaLT program helps the college realize its "responsibility for changing the system of unequal societal relationships based on race" (Allen, 1992, p. 42).

The notion of counterspaces as we use the term here is particularly important when understood as professional counterspace-an intersection of the personal and the academic that is more neutral and individual than either social spaces or academic spaces. Unlike social or residential spaces, the counterspaces of the SaLT program do not demand that students join a group or stay living there. Unlike classrooms, these counterspaces do not feel to students like places within which they must take a particular intellectual stance and stick with it. Bounded in terms of the temporal commitment they require, these spaces allow students to come and go, change and evolve, risk and change. Many of these same qualities support faculty development as well: they characterize the intersection of the personal and the academic in a confidential space and time set apart from the rest of faculty responsibilities in which learning and growth are invited, supported, and affirmed by the institution.

\section{The SaLT Program Situated in the Literature}

The SaLT program as counterspace sits at the intersection of scholarship on student voice, faculty development that includes students as partners, and critical race theory.

Student voice, developed largely in the context of K-12 schools in Australia (Holdsworth, 2000), Canada (Levin 2000), and the United Kingdom (Fielding 2004, 2006; Rudduck 2007), embraces a students' rights perspective. The basic premises of this work are that young people have unique perspectives on learning and teaching, that their insights warrant not only the attention but also the responses of adults, and that they should be afforded opportunities to actively shape their education (Cook-Sather, 2006, 2009b). "Voice" can be understood as the actual practice of each person speaking as and for herself but also as the valuing of what is said collectively by students as a group as essential contributions to dialogue that informs action. Positive manifestations of voice include the presence of, active participation in, and influence of students within conversations about and reform of educational practice. But voice can also be problematic-reduced to tokenism and manipulation (Fielding, 2004; Lodge, 2005). 
The amplification of student voices does not assert or imply the silencing or muting of faculty or other voices. Voice as metaphor suggests a resonance beyond the singular/individual speech act-the bringing of student voices and faculty voices into dialogue such that each is informed by as well as informs the other. Collaborative models of professional development that include students as partners (Bovill, Cook-Sather, \& Felten, 2011; Cook-Sather, Bovill, \& Felten, 2013) bring the fact and spirit of student voice work to the postsecondary context. Such models position students as pedagogical consultants (Cook-Sather, 2008, 2009a, 2010, 2011, forthcoming; Cook-Sather \& Alter, 2011; Cox \& Sorenson, 1999) and members of teams with faculty and staff who design or redesign course curricula (Bovill, 2013; Delpish et al., 2010). Through these and other programs, students are not only partners but also change agents, a term that "explicitly supports a view of the student as 'active collaborator' and 'co-producer,' with the potential for transformation" (Dunne \& Zandstra, 2011, p. 4; see also Healey, 2012; Neary, 2010).

Recent work in the scholarship of teaching and learning (SoTL) has similarly begun to recognize students "not as objects of inquiry . . . but as co-inquirers, helping to shape key questions, gather and analyze data, and then push for change where it is needed" (Hutchings, Huber, \& Ciccone, 2011, p. 79; see also Werder \& Otis, 2010; Werder, Thibou, \& Kaufer, 2012). As in the student voice literature, students within some SoTL projects are positioned as partners with faculty members in dialogue and in action.

In focusing on the experiences of students of color in partnership with faculty, we can link the realms of student voice and faculty development to critical race theory. As Yosso, Parker, Solórzano, and Lynn (2004) have argued, "To fully understand the ways in which race and racism shape educational institutions and maintain various forms of discrimination, we must look to the lived experiences of students of color ... a as valid, appropriate, and necessary forms of data" (p. 15), this program positions students of color as both informants on their experiences and analysts of the conditions that create those experiences. Solórzano et al. (2000) explain that the basic critical race theory model consists of "five elements focusing on: (a) the centrality of race and racism and their intersectionality with other forms of subordination, (b) the challenge to dominant ideology, (c) the commitment to social justice, (d) the centrality of experiential knowledge, and (e) the transdisciplinary perspective" (p. 63). They suggest that critical race theory offers insights, perspectives, methods, and pedagogies that guide our efforts to identify, analyze, and transform the structural and cultural aspects of education that maintain 
subordinate and dominant racial positions in and out of the classroom" (Solórzano et al., 2000, p. 63).

Creating pedagogical partnerships between faculty members and students of color at once raises awareness of and begins to enact changes in structural and cultural inequities. This work confirms findings that strong faculty-student relationships at once mitigate the effects of negative campus climate (Cress, 2008) and predict academic achievement among students of color (Allen, 1992; Baker \& Griffin, 2010). Both student consultants and faculty members benefit from critical explorations of the ways in which what is considered "universal" in higher education is actually "quite limited"-is "just reflecting a particular experience" and is, "quite often, exclusionary" (Lee, 2004, p. 146).

The SaLT program supports partnerships between faculty of all backgrounds and student consultants of all backgrounds, but because our focus in this chapter is on the experiences of students of color, we do not include examples of white or international student consultants working with faculty. We focus on student consultants of color working with faculty of color and with white faculty, sharing authority and responsibility for creating more culturally sustaining pedagogy.

\section{Students of Color Sharing Authority and Responsibility}

Our findings suggest that through their participation in the SaLT program, student consultants of color experience their identities and perspectives as legitimate and important, develop their voices within the forums of the SaLT program, build confidence in their capacities as students and consultants, and feel empowered within and beyond their partnerships (Cook-Sather \& Agu, 2012). While these outcomes are consistent with outcomes for domestic and international student consultants across racial and cultural backgrounds, they are particularly significant in terms of challenging deficit notions of students of color, for those students themselves and for others.

Many students of color used the term voice to capture the experience of literally speaking more but also more metaphorically, of developing a sense of presence, power, and agency when they are positioned as consultants to faculty members. The SaLT program provides them with arenas within which voice itself can be examined, as well as developed, in a way that is unlikely in most classrooms. As one consultant explained:

I feel like being a Student Consultant literally gave me a voice. I started being more vocal in and outside of class. As an African American 
student, I used to let people tell me how I should think and act. I used to let them reprimand me for not being black in the way they'd like. Looking back on those times, I am embarrassed and vow to never let someone have that kind of power over me ever again. I attribute much of this sense of empowerment to my participation in the [SaLT program]. It made me feel like who I am is more than enough $\rightarrow$ that my identity, my thoughts, my ideas are significant and valuable.

In the context of the SaLT program, the lived experiences this student of color articulates become "significant and valuable" as part of her own process of empowerment and as "valid, appropriate, and necessary forms of data" (Yosso et al., 2004, p. 15) for faculty learning.

The sense of empowerment students of color experience leads them to see themselves as change agents: "I felt like I could create change or make an impact because I was working as a partner alongside those that are typically viewed as having the power [faculty]." Such experiences are rare for all students and particularly for underrepresented students: "A lot of times, my point of view was not considered throughout my educational experience since my demographics are underrepresented. Being a student consultant gave me a seat at the proverbial table and the courage to speak up for what I believed and wanted to see." Having a "seat at the proverbial table" means that students of color have power and legitimacy in conversations with faculty, and they model empowerment and agency for students. This is particularly important for other students of color who do not often see people of color in positions of authority. As one student consultant explained: "I think it might have been important for other students of color or underrepresented groups to have seen me in this new and 'high level' role with respect to the professor in that their perspective was welcomed, would be treated well and was valued as a driving force to change classroom dynamics." Another student consultant affirmed this conjecture: "It is empowering to see strong, passionate, intelligent and active women of color on campus be able to be in prestigious academic positions."

When students of color experience themselves and see other students of color in positions of authority, they develop confidence in contexts beyond the counterspaces of the SaLT program. As one student consultant explained: "Being a Student Consultant gave me voice as a person of color when I was not in the role of student consultant . . . by reinforcing that not only did my perspective, assessment skills and commitment to make spaces safer for underrepresented groups deeply matter-they could drive important transformation in classrooms and in the student-teacher 
relationship." Through their participation in the SaLT program, students of color develop both an individual and a more collective sense of capacity and influence with the potential for institutional change: "I think that generally we [students of color] felt like we were more a part of the larger school community. There was strength in numbers considering that our viewpoints about what we wanted to receive from our education deserved to be taken seriously and was useful not only to us, but to the professors and other students."

\section{Faculty Sharing Authority and Responsibility}

Both faculty of color and white faculty members use the counterspaces of the SaLT program to explore links between their lived identities and pedagogical commitments and to share authority and responsibility in developing culturally sustaining pedagogy.

Faculty of color are still grossly underrepresented and inequitably treated in many higher education contexts (Cook \& Córdova, 2006; Fries-Britt, Rowan-Kenyon, Perna, Milem, \& Howard, 2011; Patitu \& Hinton, 2003), despite efforts to recruit more faculty of color for reasons of equity and for their important contributions to undergraduate education (Umbach, 2006). Formerly students of color themselves and still in the minority in higher education, faculty of color also need redefined counterspaces within which to empower themselves and catalyze change. The SaLT program provides those by structuring forums for dialogue that are about sharing experiences and developing effective practices. The empowerment of students of color in the role of consultant and the collaborations with those students contribute to the empowerment and development of faculty.

One faculty member of color explained that "from the first moment we met," she and her consultant talked about questions of race and culturally sustaining pedagogy because they both "self-identified." One of her enduring questions was "how to make academia a better place" for students of color. This faculty member articulated the potential of real, deep, difficult conversation-the kind she had with her student consultant-to effect learning and growth: "Dealing with the uncomfortable places real conversations can take you allows you to reconstruct more productive approaches to the classroom." The counterspaces of the SaLT program provide a context and support for those conversations, positioning students of color as sources of knowledge and partners to faculty of color in extending and building on that knowledge as it intersects with their own. 
Another faculty member of color commented on how the positioning of student consultants of color benefits the students enrolled in her courses and reshapes her sense of her own participation in the teaching and learning enterprise. Her courses enroll a majority of students of color, and, as she explained, "For them to see my consultants, who were both students of color, come in and to know that students of color can be authorities in the classroom, was incredibly transforming and powerful for the students who were actually participating in the class." As an experienced faculty member of color who confronts racial dynamics within and beyond her courses, this faculty member also commented on the effect of working with student consultants on her own practice. Speaking to the spirit of partnership she felt in working with her consultants and in the SaLT program overall, she voiced her relief at recognizing that she "can share the responsibility for what happens in the classroom with students... [and she need not] be the only voice speaking."

The kind of dialogue and sharing of responsibility these two faculty members describe extends beyond the faculty-student partnership within the SaLT program to inform pedagogical practice and student participation. This form of professional development is a kind of learning to speak with, learning to share the space of-and responsibility for-the classroom; it is work that has institutional impact as it carries beyond the classes on which faculty focus for this program and into their other courses and relationships.

For white faculty members, the SaLT program affords an opportunity to access and learn from the experiences and perspectives of students of color that they might not otherwise have. Developing ways of speakingand listening-across differences is one important dimension of culturally sustaining pedagogy. One faculty member wrote that being in partnership with a student consultant of color gave her a space within which to develop strategies in her ongoing effort "to speak more openly and frankly about race." Her student consultant offered "suggestions for how to redirect the conversation, how to call out students, or how to support other students in the class to contest [racist] views." Another faculty member explained that "listening to and talking with [my consultant] after class widened my interpretations and often cleared the way for me to listen and see more sensitively and with expanded or adjusted context in subsequent classes." These examples highlight how, in conversation across their differences of identity and perspective, student consultants of color and white faculty together develop heightened awareness and concrete practices for pursuing culturally sustaining pedagogy. 
These faculty members highlight the enduring influence of their work with student consultants of color. Another white faculty member who worked with three different student consultants of color commented that one of her student consultant's experiences "of some particular class activities and discussions - seen and responded to through her lens as a student of color-strongly influenced and continue to inform my understanding of what's going on in the classroom" (see Cook-Sather, Cohen, \& Shumate, 2011). Like the other faculty members quoted here, this faculty member both comes to understand her own perception and practice differently and also develops a keener awareness of the opportunities she structures for diverse student affirmation and engagement.

In their positions as consultants, students of color change what faculty-and, in turn, students in those faculty members' courses-can see and envision. Through their insights developed within the redefined counterspaces of the SaLT program, faculty members, like student consultants, develop capacity and agency to create classrooms that welcome the experiences and perspectives of diverse students. These processes begin to effect change in higher education. When the identities, experiences, and knowledge of students of color are deemed legitimate resources rather than deficits as part of a humanizing effort that affords wide access, the need for counterspaces outside the classroom is reduced.

\section{Challenges and Drawbacks}

The challenges and drawbacks of this work center around vulnerability (during the experience) and frustration (with other contexts and people who do not share the willingness to be vulnerable in this way).

Student consultants initially worry that they are vulnerable to faculty dismissal. One student consultant of color explained, "These profs have been doing this for quite some time, they have advanced degrees, you're a kid with some college. You are trying to come in and say, 'Do this better, do that.' You could easily be dismissed." Faculty vulnerability is the flip side of this fear. White faculty members talk about how it is "wonderful and also scary at times" to have students of color observe and analyze their teaching because while such students "have a certain legitimacy," they also make faculty "feel more exposed" because these students might be "able to see all the things that were problems" in the faculty member's classroom. For faculty of color, the need to reposition students in this way is a painful reminder of their "own, often marginalized experiences as students of color," of the vulnerability many still feel as people of color in the academy, and of the enduring need to change both higher education and the larger society. 
The frustration both consultants and faculty feel focuses on the difficulty of accepting that one cannot always be in such open, honest partnerships. One consultant explained that in exploring issues of difference and otherness, "one of the strengths of being a student consultant is that you can challenge the professor to think about times in their lives when they have felt privileged." She lamented what a contrast that kind of engagement can be to "the real world": "Some people are really afraid of it in the real world, I've learned." A faculty member explained a related frustration, born of institutional hierarchy and expectations, of not yet having found a way to extend such open partnership to all students: "There are a lot of students who could have given me insight," but given the norms of higher education, "I haven't figured out how to make that part of the class."

\section{Conclusion: Moving toward Culturally Sustaining Pedagogy and Institutions}

The work students of color and faculty do through the SaLT program redefines who has authority in regard to the development of culturally sustaining pedagogy. Studen $f$ consultants' and faculty members' reflections highlight an increased sense of awareness and responsibility, fostered in a collaboration within which students of color are positioned as knowers-legitimate participants and authorities-and faculty are invited to develop more informed and culturally sustaining classroom practices. Particularly within the context of a faculty-student dynamic that counters the standard hierarchical arrangements that often reinforce white experiences and perspectives, the SaLT program invites faculty exploration and growth, guided by students of color as well as other diverse students.

As faculty and students, we should think about how to turn more of the spaces within which we interact with one another into such flexible and responsive spaces-spaces that invite not only difference but also change and growth. It is particularly important to create spaces and roles within which students of color can have strong and legitimate voices in dialogue with faculty, explore their own and others' identities, and develop a stronger sense of belonging and agency. Support more than training is key to such efforts: creating loosely structured, institutionally legitimate spaces within which faculty and students can engage in genuine dialogue is a small investment for the payoff of creating more culturally sustaining pedagogies and changing the system of unequal societal relationships based on race. 
Higher education-and society at large-suffers when students and faculty of color drop out or leave because of the campus atmosphere. We need to work toward transforming counterspaces into community spaces that affirm the presence, insights, and participation of students of color in the professional development of faculty and the creation of classroom and associated arenas conducive to learning, challenge, and affirmation for all students and faculty. This work neither aims for nor can achieve resolution. Rather, it supports what must be ongoing processes of negotiation across differences toward greater equity.

\section{REFERENCES}

Allen, W. R. (1992). The color of success: African American academic student outcomes at Predo. Harvard Educational Review, 62(1), 26-44.

Baker, V. L., \& Griffin, K. A., (2010, January/February). Beyond mentoring and advising: Toward understanding the role of "faculty developers" in student success. About Campus, 2-8.

Bovill, C. (2013). An investigation of co-created curricula within higher education in the UK, Ireland and the USA. Innovations in Education and Teaching International.

Bovill, C., Cook-Sather, A., \& Felten, P. (2011). Students as co-creators of teaching approaches, course design and curricula: Implications for academic developers. International Journal for Academic Development, 16(2), 133145. doi:http://dx.doi.org/10.1080/1360144X.2011.568690

Colbert, P. J. (2010). Developing a culturally responsive classroom collaborative of faculty, students, and institution. Journal of College Teaching and Learning, 7(11), 15-24.

Cook-Sather, A. (2006). Sound, presence, and power: Exploring "student voice" in educational research and reform. Curriculum Inquiry, 36(4), 359-390.

Cook-Sather, A. (2008). "What you get is looking in a mirror, only better": Inviting students to reflect (on) college teaching. Reflective Practice, 9(4), 473-483. doi:http://dx.doi.org/10.1080/14623940802431465

Cook-Sather, A. (2009a). From traditional accountability to shared responsibility: The benefits and challenges of student consultants gathering midcourse feedback in college classrooms. Assessment and Evaluation in Higher Education, 34(2), 231-241. doi:10.1080/02602930801956042

Cook-Sather, A. (2009b). Learning from the student's perspective: A sourcebook for effective teaching. Boulder, CO: Paradigm Publishers.

Cook-Sather, A. (2010). Students as learners and teachers: Taking responsibility, transforming education, and redefining accountability. Curriculum Inquiry, 40(4), 555-575. 
Cook-Sather, A. (2011). Teaching and learning together: College faculty and undergraduates co-create a professional development model. In J. E. Miller \& J. E. Groccia, (Eds.), To improve the academy: Resources for faculty, instructional, and organizational development, Vol. 29 (pp. 219232). San Francisco, CA: Jossey-Bass/Anker.

Cook-Sather, A. (forthcoming). Student-faculty partnership in explorations of pedagogical practice: A threshold concept in academic development. International Journal for Academic Development.

Cook-Sather, A., \& Agu, P. (2012, October 27). Students of color and faculty colleagues developing voice in the "counterspaces" of a professional development program. Paper presented at the Annual Meeting of the Professional and Organizational Development Network. Seattle, WA.

Cook-Sather, A., \& Alter, Z. (2011). What is and what can be: How a liminal position can change learning and teaching in higher education. Anthropology and Education Quarterly, 42(1), 37-53. doi:10.111//j.15481492.2010.01109.x

Cook-Sather, A., Bovill, C., \& Felten, P. (2013). Engaging students as partners in teaching o learming: A guide for faculty. San Francisco, CA: Jossey-Bass.

Cook-Sather, A., Cohen, J., \& Shumate, T. (2011). Embracing productive disruptions: Excerpts from an ongoing story of developing more culturally responsive classrooms. Teaching and Learning Together in Higher Education, 4. Retrieved from htrp://teachingandlearningtogether.blogs.brynmawr .edu/archived-issues/current-issue/embracing-productive-disruptions-excerpts -from-an-ongoing-story-of-developing-more-culturally-responsive-classrooms

Cook, B. J., \& Córdova, D. I. (2006). Minorities in higher education: Twentysecond annual status report: 2007 Supplement. Washington, DC: American Council on Education.

Cox, M. D., \& Sorenson, D. L. (1999). Student collaboration in faculty development. In M. Kaplan (Ed.), To improve the academy: Resources for faculty, instructional, and organizational development, Vol. 18 (pp. 97-106). San Francisco, CA: Jossey-Bass/Anker.

Cress, C. M. (2008). Creating inclusive learning communities: The role of studentfaculty relationships in mitigating negative campus climate. Learning Inquiry, 2(2), 95-111. doi:10.1007/s11519-008-0028-2

Delgado-Bernal, D. (2002). Critical race theory, Latino critical theory, and critical raced-gendered epistemologies: Recognizing students of color as holders and creators of knowledge. Qualitative Inquiry, 8(1), 105-126. doi:10.1177/107780040200800107

Delpish, A., Holmes, A, Knight-McKenna, M., Mihans, R., Darby, A., King, K., \& Felten, P. (2010). Equalizing voices: Student-faculty partnership in course 
design. In C. Werder \& M. M. Otis (Eds.), Engaging student voices in the study of teaching and learning (pp. 96-114). Sterling, VA: Stylus.

Dunne, E., \& Zandstra, R. (2011). Students as change agents: New ways of engaging with learning and teaching in higher education. Bristol: ESCalate Higher Education Academy Subject Centre for Education/University of Exeter.

Fasching-Varner, K. J., \& Seriki, V. D. (2012). Moving beyond seeing with our eyes wide shut. A response to "there is no culturally responsive teaching spoken here." Democracy and Education, 20(1). Retrieved from http:// democracyeducationjournal.org/cgi/viewcontent.cgi? article $=1049 \&$ context =home

Fielding, M. (2004). Transformative approaches to student voice: Theoretical underpinnings, recalcitrant realities. British Educational Research Journal, 30(2), 295-311. doi:10.1080/0141192042000195236

Fielding, M. (2006). Leadership, radical student engagement and the necessity of person-centred education. Intermational Joumal of Leadership in Education, 9(4), 299-314, doi:10.1080/13603120600895411

Fries-Britt, S. L., Rowan-Kenyon, H. T., Perna, L. W., Milem, J. F., \& Howard, D. G. (2011). Underrepresentation in the academy and the institutional climate for faculty diversity. Journal of the Professoriate, 5(1), 1-34.

Gay, G. (2002). Preparing for culturally responsive teaching. Joumal of Teacher Education, 53(2), 106-116.

Healey, M., (2012, October). Students as producers and change agents. Plenary session presented at the Meeting of the International Society for the Study of Teaching and Learning. Ontario, Canada.

Holdsworth, R. (2000). Taking young people seriously means giving them serious things to do. In J. Mason \& M. Wilkinson (Eds.), Taking children seriously. Bankstown: University of Western Sydney.

Huber, L. P. (2009). Challenging racist nativist framing: Acknowledging the community cultural wealth of undocumented Chicana college students to reframe the immigration debate. Harvard Educational Review, 79(4), 704-730.

Hutchings, P., Huber, M. T., \& Ciccone, A. (2011). The scholarship of teaching and learning reconsidered: Institutional integration and impact. San Francisco, CA: Jossey-Bass.

Lee, E. (2004). Taking multicultural, anti-racist education seriously. In K. D. Salas, R. Tenorio, S. Waters, \& D. Weiss (Eds.), The new teacher book: Finding purpose, balance, and hope during your first years in the classroom (pp. 140-150). Milwaukee, WI: Rethinking Schools Press, 1994.

Levin, B. (2000). Putting students at the centre of education reform. Journal of Educational Change, 1(2), 155-172. 
Lodge, C. (2005). From hearing voices to engaging in dialogue: Problematising student participation in school improvement. Journal of Educational Change, 6(2), 125-146. doi:10.1007/s10833-005-1299-3

Neary, M. (2010). Student as producer: A pedagogy for the avant-garde? Learning Exchange, 1(1). Retrieved from http:/www.scribd.com/doc 148662051/Neary-Student-as-Producer

Pappamihiel, N. E., \& Moreno, M. (2011). Retaining Latino students: Culturally responsive instruction in colleges and universities. Journal of Hispanic Higher Education, 10(4) 331-344.

Paris, D. (2012). Culturally sustaining pedagogy: A needed change in stance, terminology, and practice. Educational Researcher, 41(3), 93-97. doi: $10.3102 / 0013189 \times 12441244$

Patitu, C. L., \& Hinton, K. G. (2003). The experiences of African American women faculty and administrators in higher education: Has anything changed? In M. Howard-Hamilton (Ed.), New directions for student services: No. 104. Meeting the needs of African women (pp. 79-93). doi:10.1002/ss. 109

Rudduck, J. (2007). Student voice, student engagement, and school reform. In D. Thiessen \& A. Cook-Sather (Eds.), International handbook of student experience in elementary and secondary school (pp. 587-610). Dordrecht, Netherlands: Springer.

Solórzano, D., Ceja, M., \& Yosso, T. (2000). Critical race theory, racial microaggressions, and campus racial climate: The experiences of African American college students. Journal of Negro Education, 69(1/2), 60-73. Retrieved from hrtp://www.jstor.org/stable/2696265

Solórzano, D., Villalpando, O., \& Oseguera, L. (2005). Educational inequities and Latina/o undergraduate students in the United States: A critical race analysis of their educational progress. Journal of Hispanic Higher Education, 4, 272-294. doi:10.1177/1538192705276550

Umbach, P. D. (2006). The contribution of faculty of color to undergraduate education. Research in Higher Education, 47(3), 317-345. doi:10.1007 /s11162-005-9391-3

Werder, C., \& Otis, M. M. (Eds.) (2010). Engaging student voices in the study of teaching and learning. Sterling, VA: Stylus Publishing.

Werder, C., Thibou, S., \& Kaufer, B. (2012). Students as co-inquirers: A requisite threshold concept in educational development? Journal of Faculty Development, 26(3), 34-38.

Yosso, T. J., Parker, L., Solórzano, D. G., \& Lynn, M. (2004). From Jim Crow to affirmative action and back again: A critical race discussion of racialized rationales and access to higher education. Review of Research in Education, 28, 1-25. Retrieved from http://www.jstor.org/stable/3568134 